Jurnal Keperawatan Silampari

Volume 4, Nomor 1, Desember 2020

e-ISSN: 2581-1975

p-ISSN: 2597-7482

DOI: https://doi.org/10.31539/jks.v4i1.1599

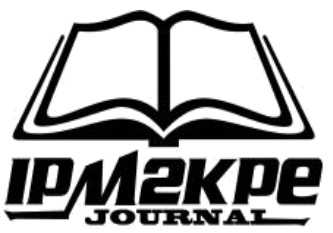

\title{
PERANGKAT EDUKASI PASIEN DAN KELUARGA DENGAN MEDIA BOOKLET (STUDI KASUS SELF-CARE DIABETES MELITUS)
}

\author{
Lilik Pranata $^{1}$, Sri Indaryati ${ }^{2}$, Novita Elisabeth Daeli ${ }^{3}$ \\ Universitas Katolik Musi Charitas ${ }^{1,2,3}$ \\ sriindaryati_iin@ukmc.ac.id ${ }^{2}$
}

\begin{abstract}
ABSTRAK
Tujuan penelitian ini adalah untuk mengetahui pengaruh edukasi dengan perangkat Booklet terhadap pengetahuan self-care diabetes. Metode dalam penelitian ini adalah penelitian kuantitatif dengan desain quasy eksperimen one group pretest-posttest design. Hasil penelitian menunjukkan bahwa dengan uji statistik Wilcoxon diperoleh nilai $\mathrm{p}=0,000<$ 0,05 yang artinya ada perbedaan pengetahuan secara signifikan pre-test dan post-test terhadap 22 responden. Rata-rata perubahan pengetahuan sebelum intervensi sebesar 12,80 dan sesudah intervensi sebesar 16,32. Simpulan, edukasi pasien dan keluarga dengan menggunakan booklet memberikan perubahan pada pengetahuan self-care diabetes melitus.
\end{abstract}

Kata Kunci: Booklet, Diabetes Melitus, Pengetahuan, Self-Care

\begin{abstract}
This study aimed to see the effect of education with the booklet on self-care diabetes knowledge. The method in this research is quantitative research with one group pretestposttest queasy experimental design. The results showed that the Wilcoxon statistical test obtained p-value $=0.000<0.05$, which means a significant difference in the pre-test and post-test knowledge of 22 respondents. The average change in intervention before the intervention was 12.80, and intervention was 16.32. In conclusion, patient and family education using booklets provides a shift in knowledge of diabetes mellitus self-care.
\end{abstract}

Keywords: Booklet, Diabetes Mellitus, Knowledge, Personal Care

\section{PENDAHULUAN}

Atlas Diabetes IDF edisi ke-9 telah memperkirakan 9,3\% penduduk dunia (463 juta) dewasa usia 20-79 tahun menderita diabetes melitus dan sekitar 4,2 juta orang dewasa berusia 20-79 tahun meninggal akibat diabetes dan komplikasinya pada tahun 2019. Ini setara dengan satu kematian setiap delapan detik. Indonesia termasuk negara ke-3 sekitar 29,1 juta dengan kasus intoleransi glukosa tertinggi setelah USA dan China (Diabetes Federation International, 2019). Indonesia mengalami peningkatan prevalensi diabetes dari 1,1\% menjadi 1,5\% pada tahun 2013 dan meningkat menjadi 2,0\% pada tahun 2018 (Santosa et al., 2019; Setyawati et al., 2020). 
Jumlah kasus di Indonesia ini akan terus meningkat akibat dari perubahan gaya hidup dan urbanisasi. Baru sekitar 50\% kasus diabetes di Indonesia dapat terdiagnosis. 50\% dari kasus yang ada hanya 2/3 kasus yang menjalani pengobatan dan baru $1 / 3$ yang menjalani pengobatan dapat mengendalikan gula darah dengan baik. Kondisi ini akan mengancam morbiditas dan mortalitas akibat komplikasi sehingga produktivitas diabetesi menjadi menurun (Soelistijo et al., 2019). Pendekatan layanan Diabetes Self-Management Education and Support (DSMES) dapat diterapkan untuk memfasilitasi pengetahuan, sikap dan keterampilan perawatan diri (Self-care) pasien diabetes melitus bersama tim kesehatan yang tersedia guna mengendalikan ancaman morbiditas dan mortalitas sekaligus pengendalian jumlah kasus yang semakin meningkat (Beck et al., 2017).

Pengelolaan perawatan mandiri (self-care) dan dukungan psikologis merupakan dasar untuk pencapaian tujuan pengobatan diabetes melalui perawatan kolaboratif untuk pemantauan yang efektif (American Diabetes Association, 2020). Pemberian informasi melalui konseling dan menggunakan booklet dapat meningkatkan prilaku patuh pasien diabetes melitus tipe 2 (Presetiawati et al., 2017).

Penelitian yang dilakukan Larasati et al., (2019) menunjukan bahwa skor tingkat pengetahuan memiliki nilai rata-rata 12. Sebagain besar jawaban pasien diabetes masih salah, terutama pada materi terkait etiologi dan self-care diabetes yaitu makan terlalu banyak gula dan makanan manis (97\%), olahraga teratur akan meningkatkan kebutuhan hormon insulin atau obat diabetes (82\%), reaksi insulin disebabkan oleh makanan yang terlalu banyak (84\%) dan penderita diabetes sebaiknya membersihkan luka dengan betadin dan alkohol (88\%). Pasien yang mencapai target terapi atau kadar gula darah terkontrol sebesar 106 (53\%) pasien. Uji chi square menunjukan tidak terdapat hubungan antara tingkat pengetahuan terhadap outcome klinik ( $\mathrm{p}=0,328)$. Hasil penelitian ini dapat menjadi masukan dan evaluasi konten edukasi pada pasien diabetes.

Peran edukator bila dilihat dari segi kejelasan materi mengenai komplikasi akut dinyatakan bahwa hanya 25 responden (49\%) saja yang menyatakan peran perawat baik, sedangkan $26(51 \%)$ responden lain menyatakan peran perawat sebagai edukator masih buruk. Dari segi materi komplikasi kronik, peran edukator digambarkan juga masih buruk oleh 69\% responden. Observasi di lapangan menunjukkan bahwa dokumentasi edukasi pasien DM tahun 2019 yang dilakukan perawat menunjukkan bahwa materi edukasi sama pada setiap pasien yaitu edukasi diit dan olah raga. Tidak ada satupun bukti dokumentasi edukasi pasien yang menunjukkan bahwa pasien telah diberikan edukasi mengenai komplikasi penyakit diabetes seperti yang dianjurkan dalam materi edukasi diabetes melitus (Indaryati \& Pranata, 2019). Hasil penelitian mengenai peran perawat dalam hubungannya dengan persepsi sakit telah didapatkan hasil yang signifikan dengan $p$ value < 0,001; R: 0,433. Tingkat korelasi dedang, negative yang berarti terbukti semakin tinggi nilai peran edukator semakin rendah persepsi sakit pasien sehingga semakin kecil komplikasi yang dirasakan oleh pasien (Anggraeni et al., 2020).

Pemberian edukasi dengan berbagai media dapat memberikan manfaat untuk peningkatan pengetahuan dan perilaku. Pemberian edukasi melalui layanan pesan singkat dan booklet dapat meningkatkan kepatuhan tetapi tidak berbeda signifikan antara kedua kelompok $(\mathrm{p}>0,05)$. Pada penelitian yang menguji pengaruh edukasi menggunakan media layanan pesan singkat dan booklet ini menunjukkan hasil bahwa adanya peningkatan kepatuhan pada kelompok layanan pesan singkat $(1,15 \pm 1,04)$ dan kelompok booklet 
$(3,22 \pm 1,99)$. Peningkatan pengetahuan mengenai katarak juga diberikan dengan menggunakan media booklet telah terbukti memberikan pengaruh signifikan melalui uji statistik wilcoxon test yaitu diperoleh $p$ value $0,000(<0,05)$ (Sylvia et al., 2019).

Saat ini masih banyak pasien diabetes yang masih kurang mengerti tentang perawatan mandiri diabetes melitus, meskipun sudah banyak pengarahan dan penyuluhan oleh puskesmas sekitar. Peran perawat sebagai edukator diabetes di Puskesmas Palembang menurut pasien digambarkan secara umum bahwa 54,90\% menyatakan peran perawat baik; sedangkan $45,09 \%$ menyatakan bahwa peran perawat masih buruk. Perangkat untuk mengedukasi masyarakat juga terlihat kurang memadai, sehingga booklet yang telah yang telah disusun sesuai dengan kebutuhan dan kemampuan daya serap pengetahuan sesuai budaya pasien dan telah memenuhi validitas konten akan diuji apakah dapat mempengaruhi pengetahuan pasien (Indaryati, 2019).

Penelitian sebelumnya menggunakan instrumen penelitian yang sudah biasa digunakan untuk mengukut pemahaman pasien DM, namun penelitian ini menggunakan 21 instrument disusun sendiri berdasarkan materi pada booklet panduan perawatan mandiri diabetes melitus tipe 2 dan telah diuji validitasnya pada pasien diabetes di Wilayah kerja Puskesmas Talang Betutu Palembang pada Area yang berbeda. Materi pada kuesioner bersumber pada booklet sebagai media edukasi untuk memfasilitasi proses pembentukan self-care diabetes.

\section{METODE PENELITIAN}

Penelitian ini merupakan penelitian jenis penelitian kuantitatif dengan one-grup pretespost-test design. Populasi penelitian adalah semua pasien DM yang pernah berkunjung di Puskesmas Talang Betutu di Kecamatan Sukarame Palembang. Instrumen penelitian menggunakan 20 item pertanyaan mengenai pengetahuan self-care DM. Sampel penelitian berjumlah 22 responden yang dilakukan pada bulan Agustus 2020.

Tahapan pada metode penelitian diuraikan dari tahap persiapan dan pelaksanaan. Pada Tahap Persiapan. Peneliti melakukan studi pendahuluan untuk memperjelas permasalahan mengapa dan bagaimana pengetahuan self-care pasien DM masih rendah, meskipun pasien sering kontak dengan petugas kesehatan dan telah tersedia berbagai informasi dari berbagai sumber. Pada tahap ini peneliti juga mengumpulkan informasi mengenai media yang tepat dapat memfasilitasi pengetahuan self-care DM. Peneliti juga mengevaluasi kelayakan dan menyediakan media booklet, alat penunjang berupa glukometer (alat ukur gula darah) dan model gizi serta merancang kuesioner untuk mengukur pengetahuan self-care DM yang memenuhi syarat validitas dan reabilitas.

Pada tahap pelaksanaan penelitian, peneliti melibatkan enumenator 4 orang yang melaksanakan penelitian guna mencegah kelebihan beban saat melakukan intervensi yang cukup berat bila hanya dikerjakan oleh 3 peneliti. Adapun aktivitas yang dilakukan peneliti dan enumenator adalah (1) Mengukur pengetahuan self-care DM pada pasien-pasien DM yang merupakan pasien kelolaan Puskesmas Talang Betutu (2) Memberikan edukasi pada pasien dan keluarga dengan media booklet, alat pengukur gula darah dan model gizi sebagai penunjang edukasi. (3) Memberikan saran agar pasien mempelajari booklet dan memberikan 1 booklet untuk dibawa pulang. (4) 1 minggu kemudian dikunjungi oleh peneliti dan enumenator dengan bantuan petugas kesehatan untuk menanyakan hal-hal yang kurang dimengerti dan memberikan kesempatan untuk bertanya serta memberikan edukasi sesuai kebutuhan dan kondisi pada pasien. (5) Memberikan kuesioner setelah edukasi yang terakhir 
untuk kelompok intervensi. Pada kelompok kontrol tidak diberikan edukasi, namun langsung diberikan kuesioner pengetahun self-care DM yang sama dengan kelompok intervensi. Pada kelompok kontrol setelah selesai pengisian kuesioner pasien dan keluarga juga diberikan edukasi dengan cara yang sama seperti pada edukasi pada kelompok intervensi serta memberikan booklet juga.

\section{HASIL PENELITIAN}

Analisis Univariat

Tabel. 1

Distribusi Frekuensi

Karakteristik Responden

\begin{tabular}{cccc}
\hline Karakteristik Responden & Kategori & Jumlah & Persentase \\
\hline \multirow{2}{*}{ Usia } & $<45$ & 3 & 13,64 \\
& $45-49$ & 6 & 27,27 \\
& $>60$ & 13 & 59,09 \\
\hline \multirow{2}{*}{ Jenis Kelamin } & Laki-laki & 6 & 27,27 \\
& Perempuan & 16 & 72,73 \\
\hline
\end{tabular}

Berdasarkan tabel 1 diketahui bahwa karakteristik mayoritas responden berada pada kelompok > 60 tahun $13(59,09 \%)$ dan mayoritas berjenis kelamin wanita $16(72,73 \%)$.

Tabel. 2

Distribusi Frekuensi Pengetahun

Pre-Test dan Post-test

\begin{tabular}{cccc}
\hline Karakteristik Responden & Kategori & Jumlah & Persentase \\
\hline \multirow{2}{*}{ Pengetahuan Pre-Test } & Tinggi & 3 & 13,64 \\
& Sedang & 10 & 45,50 \\
& Rendah & 9 & 40,90 \\
\hline \multirow{2}{*}{ Pengetahuan Post-Test } & Tinggi & 17 & 77,30 \\
& Sedang & 5 & 22,70 \\
& Rendah & 0 & 0 \\
\hline
\end{tabular}

Berdasarkan tabel 2 diketahui bahwa karakteristik mayoritas responden pada pengetahuan pre-test memiliki pengetahuan sedang, yaitu 10 (45,50\%). Sedangkan pada post-test karakteristik pengetahuan mayoritas adalah pengetahuan tinggi $(77,30 \%)$.

\section{Analisis Bivariat}

Tabel. 3

Pengaruh Edukasi dengan Perangkat Booklet terhadap Pengetahuan Self-Care Diabetes

\begin{tabular}{ccccc}
\hline Variabel & Mean & $\begin{array}{c}\text { Standar } \\
\text { Deviasi }\end{array}$ & Mean & \multicolumn{2}{c}{ Standar Deviasi } \\
\hline \multicolumn{2}{c}{ Sebelum } & \multicolumn{2}{c}{ Sesudah } \\
\hline Pengetahuan & 12,82 & 2,702 & 16,32 & 2,079 \\
Uji Statistik & $0,000<0,05$ & & & \\
\hline
\end{tabular}


Berdasarkan tabel 3 hasil uji statistik Wilcoxon diperoleh nilai $p=0,000<0,05$ yang menunjukkan adanya perbedaan secara signifikan pengetahuan self-care sebelum dan sesudah diberikan edukasi dengan menggunakan media booklet. Didapat rata-rata perubahan pengetahuan sebelum intervensi sebesar 12,82 dan sesudah intervensi sebesar 16,32.

\section{PEMBAHASAN}

\section{Analisis Univariat}

\section{Pengetahuan Pre-Test dan post-Test}

Hasil analisis univariat pada variabel pengetahuan sebelum diberikan edukasi (pre-test) masih didominasi dalam katagori pengetahuan sedang. Setelah diberikan edukasi menggunakan media booklet (post-test) menunjukkan persentase pengetahuan post-test berubah didominasi oleh responden dengan pengetahuan katagori tinggi.

Berbeda dengan hasil penelitian yang menggunakan media audiovisual didapatkan bahwa sebelum diberikan edukasi dengan media audio visual hampir seluruh responden (90\%) responden memiliki tingkat pengetahuan kurang. Namun sesudah diberikan edukasi dengan media audio visual pengetahuan kurangnya masih ada meskipun menjadi lebih sedikit yaitu hanya 45\% (Anggraini et al., 2018).

Hasil penelitian dengan memberikan intervensi konseling diabetes melitus didapatkan hasil pre-test yang menggunakan kuesioner Diabetes Knowledge Questionnaire (DKQ-24) menunjukkan bahwa responden dengan kategori pengetahuan rendah sebanyak $27 \%$, pengetahuan cukup sebanyak 65\%, dan pengetahuan tinggi 8\%. Dua minggu setelah diberikan konseling, hasil post-test dengan kuesioner yang sama menggunakan kuesioner DKQ - 24, diperoleh hasil responden dengan kategori pengetahuan rendah sebanyak 3\%, pengetahuan cukup sebanyak 77\%, dan pengetahuan tinggi sebanyak 20\% (Hanifa \& Mentari, 2020). Pada pengukuran pengetahuan yang dilakukan di beberapa tempat di Indonesia dengan responden $<100$ di atas berbeda hasil dengan penelitian yang dilakukan pada di Yordania dengan responden sebanyak 1.702 didapatkah hasil tanpa intervensi responden $(53,3 \%)$ memiliki skor pengetahuan yang baik (Alsous et al., 2019). Hasil penelitian pada post-test intervensi booklet pengetahuan kurang menjadi tidak ada. Sedangkan pada penelitian dengan memberikan edukasi dengan audio visual dan konseling masih ada yang memiliki pengetahuan katagori rendah.

Edukasi pasien diabetes melitus diberikan berbeda pada tingkat awal dan pada tingkat lanjutan. Materi yang diberikan sensuai dengan kebutuhan pasien yang mungkin berbeda pengetahuannya karena faktor-faktor lain yang mempengaruhi pengetahuan. Materi pada tingkat awal maupun lanjutan untuk pelayanan primer antara lain: proses terjadinya sakit diabetes, pentingnya mengendalikan dan memantau diabetes secara terus menerus, penyulit perawatan diabetes dan risikonya, perencanaan farmakologi dan non farmakologi, interaksi antara makanan, aktivitas fisik dan obat, cara memantau gula darah, mengenal gejala dan penanganan awal hipoglikemia, pentingnya perawatan kaki dan mamanfaatkan pelayanan Kesehatan (Soelistijo et al., 2019).

Perangkat edukasi yang digunakan pada penelitian ini menarik dan isinya sesuai dengan kebutuhan edukasi pasien diabetes melitus. Booklet di desain dengan menggunakan Microsoft word dan Microsoft publisher. Booklet berukuran 14,8 x $21 \mathrm{~cm}, 44$ halaman, isi hvs 80 gr 4/4, cover artpp 210 gr 4/4, glossy dan dijahit kawat. Warna dasar kertas dominan menggunakan warna hijau dan putih, sedangkan warna tulisan menggunakan warna hitam, 
merah. Kelayakan booklet sebagai media untuk edukasi perawatan mandiri pasien diabetes melitus ini telah divalidasi oleh 5 dosen, 3 dosen dari Keperawatan Medikal Bedah yang mengajar keperawatan pada pasien diabetes melitus dan 1 dosen dari keperawatan komunitas yang mengajarkan keperawatan keluarga dan komunitas dan 1 dosen yang mengajar promosi kesehatan. Kelima validator memberikan nilai rentang baik dan sangat baik (3-4) pada setiap kriteria. Semua kriteria booklet dinyatakan valid. Adapun nilai content validity ratio (CVR) yaitu 0.99 .

Materi pada intervensi edukasi yang diberikan difokuskan pada materi diabetes umum yaitu pengenalan diabetes dan mengenai Self-Care Diabetes Melitus tipe 2. Materi pada bagian pertama menjelaskan Pengenalan Diabetes Melitus (DM) yang terdiri dari: (1) Pengenalan diabetes melitus (2) Faktor risiko (3) Tanda dan gejala khas (4) Komplikasi dan bahaya (5) Tanda dan penyebab hipoglikemia (6) Mengatasi hipoglikemia (7) Tanda dan penyebab hiperglikemia (8) Penanganan hiperglikemia. Bagian kedua berisi: (1) Perilaku mandiri mengelola makanan sehat: Diit diabetes seuai jenis, jadwal dan jumlah makan (2) Perilaku mandiri mengatur aktivitas sehari-hari (3) Perilaku mandiri mengontrol status glikemik (4) Perilaku mandiri menggunakan obat sesuai resep dokter (5) Perilaku mandiri merawat kaki. Bagian dari materi dalam booklet dapat dilihat pada gambar 1 di bawah ini.
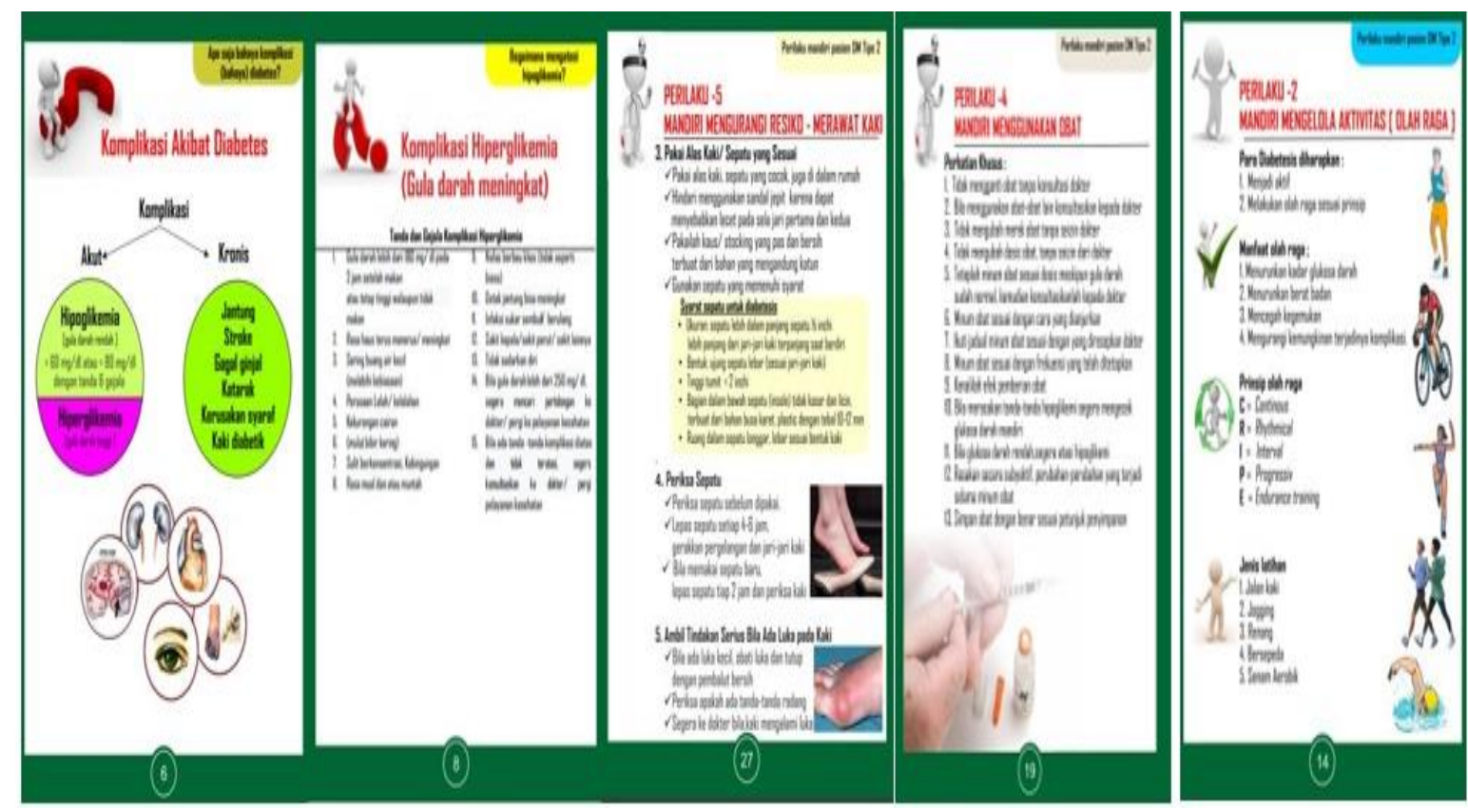

Gambar. 1

Materi Booklet: Pengenalan DM dan Perawatan Mandiri Diabetes Melitus

Pada akhir bagian materi diberikan lampiran mengenai standar diit, contoh menu, jenis dan sumber makanan serta kandungan kalori, protein dan lemak pada setiap satuan penukar makanan pada setiap golongan: golongan I Sumber karbohidrat; golongan II Protein hewani; golongan III protein nabati; golongan IV sayuran; golongan V buah dan gula; golongan VI susu; golongan VII minyak dan golongan VIII makanan tanpa kalori. Lampiran ini 
dimaksudkan agar para diabetes selalu membaca dan mengerti kandungan setiap diit yang dikomsumsi khususnya kandungan kalori dan lemak. Bagian akhir dari lampiran booklet dimasukkan lembaran untuk melakukan pencatatan hasil dari pemantauan status glikemik (indek masa tubuh, glukosa darah puasa dan 2 jam pp, HbA1C, Tekanan darah, Kolesterol total, LDL, HDL, trigliserit, Mikro albumin, pemeriksaan mata dan pemeriksaan kaki. Catatan ini sebagai pemantauan untuk evaluasi mandiri dan berguna untuk tenaga kesehatan dalam membantu menyusun intervensi guna mencapai status glikemik yang terkontrol. Tampilan cover dan lampiran booklet yang dapat dilihat dari gambar 2 dibawah ini.
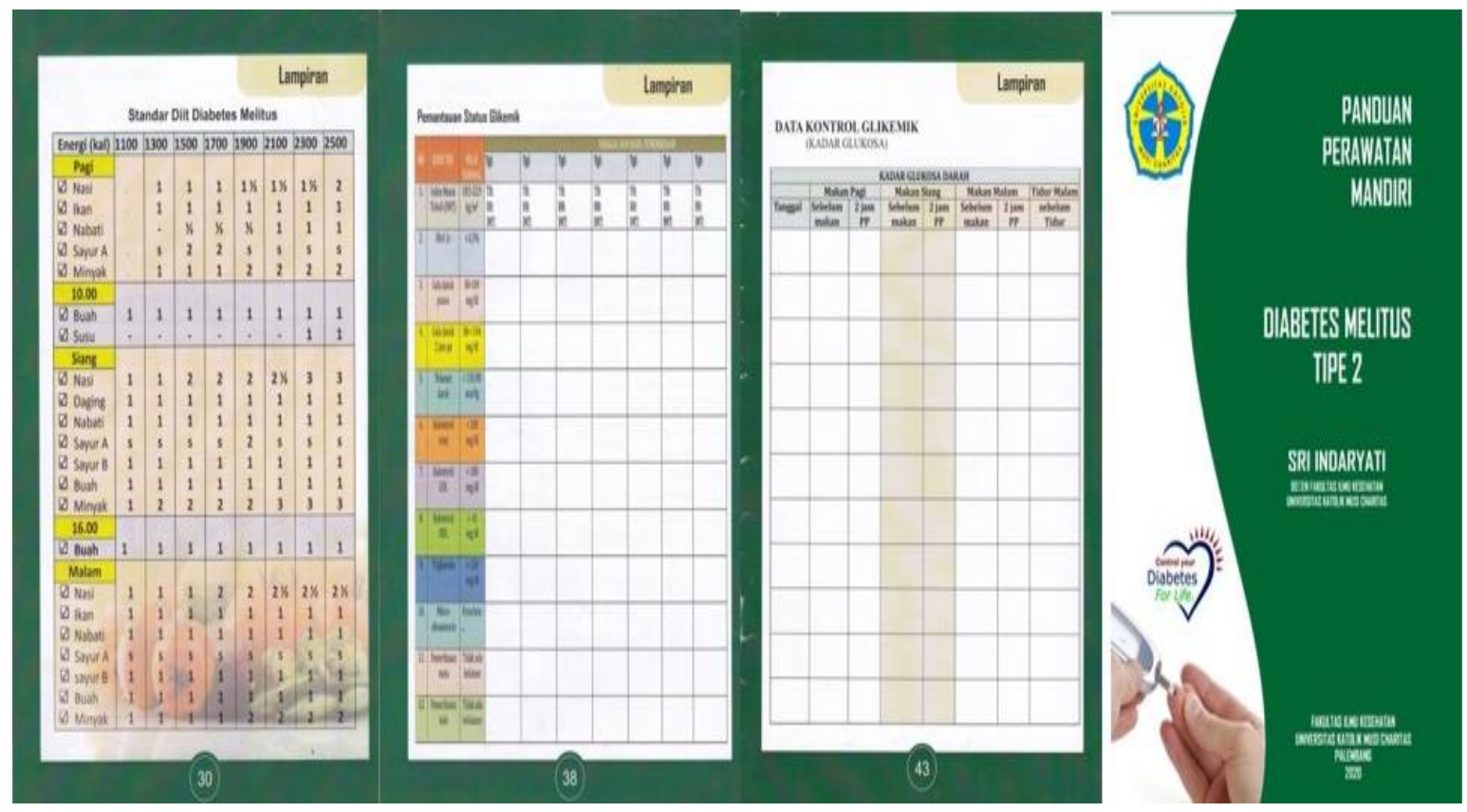

Gambar. 2

Lampiran Booklet: Standar Diit DM;

Pemantauan Glikemik dan Cover)

\section{Analisis Bivariat}

Hasil uji statistik dengan wilcoxon telah terbukti bahwa terdapat perbedaan secara signifikan pengetahuan self-care sebelum dan sesudah diberikan edukasi dengan menggunakan media booklet. Didapat rata-rata perubahan pengetahuan sebelum intervensi sebesar 12,82 dan sesudah intervensi sebesar 16,32. Peran pasien dan keluarga sangat penting dalam upaya kemandirian perawatan diri diabetes. Perawat merupakan salah satu profesi yang mempunyai peran edukator dapat upaya mendukung perawatan mandiri diabetes, sehingga para diabetesi akan memiliki pengetahuan, sikap dan perilaku self-care diabetes sehingga pasien dan keluarga memiliki kemamampuan merawat diri dan keluarganya dan dapat mencegah komplikasi secara mandiri (Soelistijo et al., 2019).

Pemberian edukasi yang baik tidak hanya diberikan secara lisan. sebaiknya ditambahkan dengan menggunakan modul, sehingga pasien dan keluarga dapat mempelajari secara terus-menerus perawatan dirinya diabetes (Oktorina et al., 2019). Alat bantu atau media edukasi dapat melibatkan lebih banyak indra manusia, sehingga seseorang akan lebih 
mudah memahami suatu objek. Semakin banyak pancaindra yang digunakan, semakin banyak dan semakin jelas pula pengertian atau pengetahuan yang diperoleh.

Materi yang diberikan tanpa media yang tepat kurang membawa hasil yang baik. Kejelasan materi pencegahan komplikasi akut diabetes yang masih kurang dinyatakan oleh oleh 26 responden (51\%) yang ada di Wilayah Kerja Puskesmas Talang Betutu. Sedangkan pada materi pencegahan komplikasi kronis diabetes sebagian besar yaitu 36 responden (71\%) juga menyatakan kurang jelas. Namun Sebagian besar responden yaitu 42 responden (82\%) menyatakan sikap perawat dalam memberikan edukasi sudah baik (Indaryati, 2019).

Edukasi dengan menggunakan self-instructional module juga telah diteliti pengaruhnya terhadap peningkatan pengetahuan pasien diabetes melitus. Penelitian ini menggunakan desain quasi experimental dengan one group pretest postest dengan jumlah sampel 29 orang dengan diagnosa diabetes melitus tipe 2, pengumpulan data menggunakan kuesioner. Analisis statistik menggunakan wilcoxon test. Hasil penelitian menunjukkan bahwa terdapat perbedaan pengetahuan $(\mathrm{p}<0,001 ; \alpha<0,05)$ sebelum dan sesudah edukasi dengan selfinstructional module (Oktorina et al., 2019). Penelitian yang dilakukan Padila et al., (2020) menunjukkan bahwa terdapat pengaruh yang signifikan anatara metode demonstrasi terhadap peningkatan kemampuan cuci tangan tujuh langkah pada anak usia dini di Taman KanakKanak Aisyiyah 1 Kota Bengkulu.

Hasil penelitian Kusnanto et al., (2019) menunjukkan bahwa tingkat pengetahuan $(\mathrm{p}=0,049 ; \mathrm{r}=-0,192)$ dan diabetes self- management $(\mathrm{p}=0,000 ; \mathrm{r}=-0,341)$ memiliki hubungan terhadap tingkat stres saat menjalani diet. Diabetes self- management memiliki hubungan yang sangat kuat dari pada tingkat pengetahuan terhadap tingkat stres pasien diabetes yang menjalani diet.

Penelitian Wiastuti et al., (2017) Uji dependent t-test menunjukan adanya penurunan signifikan nilai rata-rata stres baik pada kelompok perlakuan maupun kelompok kontrol dengan nilai $p=0,000$. Independent- $t$ test menunjukan adanya perbedaan nilai rata-rata stres antara kelompok perlakuan dan kelompok kontrol $(\mathrm{p}=0,001)$. Dari hasil penelitian dapat disimpulkan terdapat pengaruh signifikan DSME/S terhadap penurunan stres pada pasien DM tipe 2 di wilayah kerja Puskesmas Patrang Kabupaten Jember.

Perbedaan bermakna perawatan diri diabetik pada pasien Diabetes Mellitus tipe 2 setelah penerapan Pendidikan Manajemen Mandiri Diabetes (DSME) dengan nilai $\mathrm{p}=0,00$. Kesimpulannya, program DSME dapat diterapkan secara sistematis dan berkelanjutan sebagai intervensi keperawatan kepada pasien dengan menggunakan media dan metode pendidikan yang tepat sehingga dapat mengontrol dan mencegah komplikasi Diabetes Mellitus tipe 2 (Sudirman, 2017).

\section{SIMPULAN}

Edukasi pasien dan keluarga dengan menggunakan booklet memberikan perubahan pada pengetahuan self-care diabetes melitus.

\section{SARAN}

Disarankan kepada petugas Kesehatan dapat memfasilitasi pengetahuan dengan media yang sesuai dengan kebutuhan pasien dan sesuai budaya pasien. 


\section{DAFTAR PUSTAKA}

Alsous, M., Jalil, M. A., Odeh, M., Kurdi, R. Al, \& Alnan, M. (2019). Public Knowledge, Attitudes and Practices Toward Diabetes Mellitus: A Cross-Sectional Study from Jordan. PLoS ONE, 14(3), 1-12. https://doi.org/10.1371/journal.pone.0214479

American Diabetes Association. (2020). Facilitating Behavior Change and Well-Being to Improve Health Outcomes: Standards of Medical Care in Diabetes-2020. Diabetes Care, 43(1), S48-S65. https://doi.org/10.2337/dc20-S005

Anggraeni, N. C., Widayati, N., \& Sutawardana, J. H. (2020). Peran Perawat sebagai Edukator terhadap Persepsi Sakit pada Pasien Diabetes Mellitus Tipe 2 Kabupaten Jember. Jurnal Pendidikan Keperawatan Indonesia. doi.org/10.17509/jpki.v6i1.24364

Anggraini, N. R. F., Hariyanto, T., \& Warsono. (2018). Perbedaan Tingkat Pengetahuan Tentang Diabetes Mellitus (DM) Tipe II Sebelum dan Sesudah Diberikan Edukasi dengan Media Audio Visual pada Penderita Diabetes Mellitus Tipe II di Dusun Sentong Desa Karangduren Kecamatan Pakisaji Kabupaten Malang. Nursing News, 3(1), 492-500. https://publikasi.unitri.ac.id/index.php/fikes/article/view/822

Beck, J., Greenwood, D. A., Blanton, L., Bollinger, S. T., Butcher, M. K., Condon, J. E., Cypress, M., Faulkner, P., Fischl, A. H., Francis, T., Kolb, L. E., Lavin-Tompkins, J. M., MacLeod, J., Maryniuk, M., Mensing, C., Orzeck, E. A., Pope, D. D., Pulizzi, J. L., Reed, A. A., \& Wang, J. (2017). 2017 National Standards for Diabetes SelfManagement Education and Support. Diabetes Care, 40(10), 1409-1419. https://doi.org/10.2337/dci17-0025

Diabetes Federation International. (2019). IDF Diabetes Atlas Ninth edition 2019. In International Diabetes Federation

Hanifa, D. N. C., \& Mentari, I. A. (2020). Pengaruh Pemberian Konseling Menggunakan Booklet terhadap Pengetahuan Diabetes Mellitus Masyarakat di Kecamatan Anggana, Kalimantan Timur. Jurnal Ilmiah Ibnu Sina, 5(1), 20-26. Doi: 10.36387/jiis.v5i1.367

Indaryati, S., \& Pranata, L. (2019). Peran Edukator Perawat dalam Pencegahan Komplikasi Diabetes Melitus (DM). Universitas Katolik Musi Charitas

Indaryati S, P. L. (2019). Peran Edukator Perawat Dalam Pencegahan Komplikasi Diabetes Melitus (Dm) Di Puskesmas Kota Palembang Tahun 2019. Prosiding Seminar Nasional \& Diseminasi Hasil Penelitian Update Evidence-Based Practice in Cardiovascular Nursing, 14-28. https://core.ac.uk/download/pdf/323514423.pdf

Kusnanto, K., Sundari, P. M., Asmoro, C. P., \& Arifin, A. (2019). Hubungan Tingkat Pengetahuan dan Diabetes Self-Management dengan Tingkat Stres Pasien Diabetes Melitus yang Menjalani Diet. Keperawatan Indonesia, 22(1), 34-41. DOI: 10.7454/jki.v22i1.780

Larasati, L. A., Andayani, T. M., \& Kristina, S. A. (2019). Hubungan Tingkat Pengetahuan terhadap Outcome Klinik Pasien Diabetes Melitus Tipe 2. Jurnal Manajemen dan Pelayanan Farmasi (Journal of Management and Pharmacy Practice), 9(2), 101-108. https://doi.org/10.22146/jmpf.43489

Oktorina, R., Sitorus, R., \& Sukmarini, L. (2019). Pengaruh Edukasi Kesehatan dengan Self Instructional Module terhadap Pengetahuan tentang Diabetes Mellitus. Jurnal Endurance, 4(1),171. https://doi.org/10.22216/jen.v4i1.2995 
Padila, P., Andri, J., Harsismanto, J., Andrianto, M. B., \& Admaja, R. D. (2020). Pembelajaran Cuci Tangan Tujuh Langkah melalui Metode Demonstrasi pada Anak Usia Dini. Journal of Telenursing (JOTING), 2(2), 112-118. https://doi.org/10.31539/joting.v2i2.1395

Presetiawati, I., Andrajati, R., \& Sauriasari, R. (2017). Effectiveness of a Medication Booklet and Counseling on Treatment Adherence in Type 2 Diabetes Mellitus Patients. International Journal of Applied Pharmaceutics, 9, 27-31. https://doi.org/10.22159/ijap.2017.v9s1.24_29

Santosa, A., Gustiawan, A., Putra, R. A. N., \& Chasanah, N. (2019). Body Mass Index to Predict Pre-Diabetes. Ethiopian Journal of Health Development, 33(1), 38-45. https://www.researchgate.net/publication/332091629_Body_Mass_Index_to_Predict_ Pre-diabetes

Setyawati, A. D., Ngo, T. H. L., Padila, P., \& Andri, J. (2020). Obesity and Heredity for Diabetes Mellitus among Elderly. JOSING: Journal of Nursing and Health, 1(1), 2631. https://doi.org/https://doi.org/https://doi.org/10.31539/josing.v1i1.1149

Soelistijo, S. A., Lindarto, D., Decroli, E., Permana, H., Sucipto, K. W., Kusnadi, Y., Budiman., \& Ikhsan, R. (2019). Pedoman Pengelolaan dan Pencegahan Diabetes Melitus Tipe 2 Dewasa di Indonesia 2019. Perkumpulan Endokrinologi Indonesia, 1117. https://pbperkeni.or.id/pengelolaan-pencegahan-diabetes-melitus

Sudirman, A. A. (2017). Diabetes Mellitus, Diabetes Self Management Education (DSME), and Self Care Diabetik. Proceeding Gorontalo Int. Nurs. Conf, 1-11. DOI: $10.31227 /$ osf.io/8kgpr

Sylvia, E. I., Azizah, I., Manuntung, A., \& Datak, G. (2019). Peningkatan Pengetahuan Pasien Diabetes Melitus melalui Edukasi Tentang Katarak dengan Media Booklet. Jurnal Ilmiah Permaa: Jurnal Ilmiah Stikes Kendal, 9(4), 353-358. http://journal.stikeskendal.ac.id/index.php/PSKM/article/view/582

Wiastuti, S. M., Rondhianto, R., \& Widayanti, N. (2017). Pengaruh Diabetes Self Management Education and Support (DSME/S) terhadap Stres pada Pasien Diabetes Mellitus (DM) Tipe 2 di Wilayah Kerja Puskesmas Patrang Kabupaten Jember. Jurnal Pustaka Kesehatan, $5(2)$ $260-275$. https://jurnal.unej.ac.id/index.php/JPK/issue/view/528 